Archives of Agriculture and Environmental Science

\title{
Growth performance of aromatic Boro rice (Oryza sativa L. cv. BRRI dhan50) as influenced by date of transplanting and nutrient management
}

\author{
Nilufar Yeismin Nila, Swapan Kumar Paul* (D) and Md. Abdur Rahman Sarkar \\ Department of Agronomy, Bangladesh Agricultural University, Mymensingh-2202, BANGLADESH \\ "Corresponding author's E-mail: skpaul@bau.edu.bd
}

\section{ARTICLE HISTORY}

Received: 13 April 2018

Accepted: 30 May 2018

\section{Keywords}

Aromatic Boro rice

Date of transplanting

Growth performance

Morpho-physiological characteristics

Nutrient management

\begin{abstract}
The present experiment was conducted at the Agronomy Field Laboratory, Bangladesh Agricultural University, Mymensingh, during December 2015 to May 2016 to find out the effect of transplanting date and nutrient management on the growth performance of aromatic Boro rice (cv. BRRI dhan50). The experiment comprised five dates of transplanting viz. 15 December, 30 December, 15 January; 30 January and 15 February, and four nutrient managements viz., recommended dose of inorganic fertilizer (N, P, K, S and Zn @ 115, 25, 60, $18,3.5 \mathrm{~kg} \mathrm{ha}^{-1}$, respectively), poultry manure @ $5 \mathrm{t} \mathrm{ha}^{-1}, 25 \%$ less than recommended dose of inorganic fertilizer + poultry manure @ $2.5 \mathrm{t} \mathrm{ha}^{-1}, 50 \%$ less than recommended dose of inorganic fertilizer + poultry manure @ $2.5 \mathrm{t} \mathrm{ha}^{-1}$. The experiment was laid out in a randomized complete block design with three replications. Morpho-physiological characteristics were significantly influenced by date of transplanting, nutrient management and their interactions. The highest plant height $(71.41 \mathrm{~cm}$ ) was recorded in early transplanting (15 December) and the lowest plant height $(66.29 \mathrm{~cm})$ was recorded when transplanted on 15 February. At 75 DAT, the tallest plant $(72.79 \mathrm{~cm})$, the highest number of tillers hill ${ }^{-1}(15.13)$ and LAI (2.78) were obtained in $25 \%$ less than recommended dose of inorganic fertilizers + poultry manure @ $2.5 \mathrm{t}$ $\mathrm{ha}^{-1}$ and the shortest plant $(66.63 \mathrm{~cm})$ and lowest number of tillers hill ${ }^{-1}(11.13)$ were recorded when applied only poultry manure @ $5 \mathrm{t} \mathrm{ha}^{-1}$. The highest dry matter production hill $^{-1}(31.18 \mathrm{~g})$ at 75 DAT was obtained when the crop was transplanted on 15 December and fertilized with $25 \%$ less than recommended dose of inorganic fertilizers + poultry manure @ $2.5 \mathrm{t} \mathrm{ha}^{-1}$. Therefore, aromatic Boro rice (cv. BRRI dhan50) can be transplanted on 15 December fertilized with $25 \%$ less than recommended dose of inorganic fertilizers + poultry manure @ $2.5 \mathrm{t} \mathrm{ha}^{-1}$ for appreciable growth performance.
\end{abstract}

(C)2018 Agriculture and Environmental Science Academy

Citation of this article: Nila, N.Y., Paul, S.K. and Sarkar, M.A.R. (2018). Growth performance of aromatic Boro rice (Oryza sativa L. cv. BRRI dhan50) as influenced by date of transplanting and nutrient management. Archives of Agriculture and Environmental Science, 3(2): 116-122, https://dx.doi.org/10.26832/24566632.2018.030203

\section{INTRODUCTION}

Rice (Oryza sativa L.) is an important food crop and a primary food source for more than one-third of world's population (Singh and Singh, 2008; Aljumaili et al., 2018). Nearly 77.07\% of cropped area of Bangladesh is used for rice production, with annual production of 34.71 million ton from 11.42 million hectare of land (BBS, 2016). Scented rice contributes a small but special group of rice which covers $2 \%$ of the national rice acreage of Bangladesh and $12.5 \%$ of the total transplant Aman rice cultivation (Ashrafuzzaman et al., 2009). BRRI dhan50 (Banglamoti), a high yielding variety of aromatic rice has been developed by Bangladesh Rice Research Institute and recommended for Boro season. Proper growth is prerequisite for higher yield of rice. Timely transplanting and nutrient management are directly influence the growth, yield and quality of aromatic rice. Transplanting rice after the optimum dates can result in higher disease and insect incidences, tropical storm- 
related lodging, and possible heat damage during heading and the grain filling periods resulting in low yields. Even slight changes in transplanting date substantially changes growth duration and grain yields due to changes of air temperature and solar radiation (BRRI, 2003).

In Bangladesh, nutrient stresses of soils are increasing day by day. The reasons for low yield are also associated with judicious nutrient management especially of organic fertilizer like cow dung, poultry manure and/or integration with inorganic fertilizers. Cowdung and poultry manure (PM) may play a vital role in soil fertility management as well as supplying primary, secondary and micronutrients for crop production. Cowdung contains $0.5-1.5 \% \mathrm{~N}, 0.4-0.8 \% \mathrm{P}, 0.5-1.9 \% \mathrm{~K}$ and other nutrients in small quantity while the poultry manure contains high amount of secondary and micronutrients in addition to $1.6 \% \mathrm{~N}$, $1.5 \% \mathrm{P}$ and $0.85 \% \mathrm{~K}$ (Islam et al., 2014). The application of cowdung and poultry manure to soil is considered a good management practice in any agricultural production system stimulate the soil microbial growth and activity, subsequent mineralization and increased soil fertility. Organic manure may play an important role in rice cultivation when used in combination with chemical fertilizers, Combined application of manure with inorganic fertilizers increased morpho-physiological characteristics of rice was reported elsewhere (Islam et al., 2014; Sarkar et al., 2016; Jahan et al., 2017). The efficient nutrient management enhances crop growth, yield, and quality and at the same time reduces fertilization cost. So, extensive research works is necessary to find out the influence of date of transplanting and nutrient management on growth performance of aromatic Boro rice (cv. BRRI dhan50).

\section{MATERIALS AND METHODS}

\section{Description of experimental site}

The experiment was conducted at the Agronomy Field Laboratory, Bangladesh Agricultural University, Mymensingh, during the period from December 2015 to May 2016. The experimental site is located at $24.75^{\circ} \mathrm{N}$ latitude and $90.50^{\circ} \mathrm{E}$ longitude at an elevation of $18 \mathrm{~m}$ above the sea level. The site belongs to the non-calcareous dark grey floodplain soil under the Agro-ecological Zone of the Old Brahmaputra Floodplain (AEZ-9) (UNDP and FAO, 1988). The soil of the experimental field was characterized by non-calcareous dark grey floodplain soils with $1.29 \%$ organic matter content. The experimental field was a medium high land having $\mathrm{pH}$ 6.8. BRRI dhan50 (Banglamoti), a modern fine rice variety, was used as the test variety.

\section{Experimental design}

The study consisted of five date of transplanting viz. 15 December $\left(D_{1}\right), 30$ December $\left(D_{2}\right), 15$ January $\left(D_{3}\right), 30$ January $\left(D_{4}\right)$ and 15 February $\left(D_{5}\right)$, and four nutrient managements viz. recommended dose of inorganic fertilizers (N, P, K, S and Zn @ 115, $25,60,18,3.5 \mathrm{~kg} \mathrm{ha}^{-1}$, respectively) $\left(F_{1}\right)$, poultry manure @ $5 \mathrm{t}$ $\mathrm{ha}^{-1}\left(\mathrm{~F}_{2}\right), 25 \%$ less than recommended dose of inorganic fertiliz- ers + poultry manure @ $2.5 \mathrm{t} \mathrm{ha}^{-1}\left(\mathrm{~F}_{3}\right), 50 \%$ less than recommended dose of inorganic fertilizers + poultry manure @ $2.5 \mathrm{t}$ ha ${ }^{-1}\left(F_{4}\right)$. The experiment was laid out in a factorial randomized complete block design with three replications. Each of the replication represents a block in the experiment. Each block was divided into 20 unit plots where 20 treatment combinations were allocated at random. There were 60 unit plots in the experiment. The size of unit plot was $4.0 \mathrm{~m} \times 2.5 \mathrm{~m}$.

Preparation of nursery, nutrient management and transplantation

Healthy seeds were used for sprouting. Seeds were immersed in water in bucket for 24 hours and then taken out of water and packed in a moist gunny bags for incubation until sprouting. The seeds started sprouting after 48 hours and then prepared for sown in nursery bed. The seeds were sown in the seedbed on 15 November, 30 November, 15 December, 30 December and 15 January respectively with proper care. Both inorganic and organic fertilizers were applied according to the treatments. The amount of the nitrogen, phosphorus, potassium, sulphur and zinc required for each unit plot was calculated on per hectare basis. Triple super phosphate (TSP), muriate of potash (MoP), Gypsum, zinc sulphate $\left(\mathrm{ZnSO}_{4}\right)$ and poultry manure were applied at the time of final land preparation as per treatment requirements. Urea was top dressed in three equal splits at 15,30 and 45 days after transplanting (DAT). The seedbed was made wet by application of water in the morning and evening on the previous day before uprooting. The seedlings were uprooted without causing massive mechanical injury to the roots and were kept in the soft mud in shade. Thirty-day old seedlings were transplanted on 15 December 2015, 30 December 2015, 15 January 2016, 30 January 2016 and 15 February 2016, respectively in the well puddled plot. Transplanting was done by using two seedlings hill ${ }^{-1}$ with $25 \mathrm{~cm} \times 15 \mathrm{~cm}$ spacing between the rows and hills, respectively.

\section{Observation and data collection}

Five hills were randomly selected soon after transplanting and marked with bamboo sticks in each plot excluding border rows to record the data on plant height and number of tillers hill $^{-1}$ at 15-day intervals beginning 15 DAT up to 75 DAT. To record the total dry matter, two plants were randomly selected excluding border rows and central $1 \mathrm{~m}^{2}$ area at 15-day intervals beginning 15 DAT up to 75 DAT. To determine leaf area index leaf samples were collected from one hill from each plot at 65 DAT. Leaf blades were separated and leaf area was measured by using a leaf area meter at the Professor Muhammad Hussain Central Laboratory, Bangladesh Agricultural University, Mymensingh. LAI was calculated by the following standard formula as shown below.

$$
\mathrm{LAI}=\mathrm{LA} / \mathrm{P}
$$

Where, $\mathrm{LA}=$ Leaf area and $\mathrm{P}=$ Ground area. 
Statistical analysis of data

Data were compiled and tabulated in proper form for statistical analysis. The recorded data were statistically analyzed to find out the significance of variation resulting from the experimental treatments. All the collected data were analyzed adjudged by Duncan's Multiple Range Test (DMRT) (Gomez and Gomez, 1984).

\section{RESULTS AND DISCUSSION}

\section{Plant height}

Plant height was significantly influenced by transplanting dates (Table 1). The plant height gradually increased with the advancement of transplanting dates. At 60 DAT, the tallest plant $(67.35 \mathrm{~cm})$ was recorded when the crop was transplanted on 30 January. Crop transplanted on 30 December and 15 January showed at par results with that of 30 January. On the other hand, the shortest plant $(60.21 \mathrm{~cm})$ was recorded at 60 DAT when the crop was transplanted on 15 December. Significant variation due to nutrient management was found on the plant height at all sampling dates. At 75 DAT, the tallest plant $(72.79 \mathrm{~cm})$ was obtained in $\mathrm{F}_{3}(25 \%$ less than recommended dose of inorganic fertilizers + poultry manure @ $\left.2.5 \mathrm{t} \mathrm{ha}^{-1}\right)$ and the shortest one $\left(66.63 \mathrm{~cm}\right.$ ) obtained in $\mathrm{F}_{2}$ (Poultry manure @ 5 $\mathrm{t} \mathrm{ha}^{-1}$ ) (Table 1). Islam et al. (2014) reported that poultry manure incorporation with chemical fertilizer increased plant height and 50\% BRRI recommended dose of chemical fertilizers + poultry manure @ $2.5 \mathrm{t} \mathrm{ha}^{-1}$ produced the tallest plants compared to sole application of manures and recommended fertilizers The plant height was not statistically significant at all dates of sampling due to interaction between date of transplanting and nutrient management.

\section{Number of tillers hill ${ }^{-1}$}

The number of total tillers hill ${ }^{-1}$ differed significantly due to date of transplanting. The results showed that tiller number was increased with the advancement of time up to 60 DAT and decreased thereafter (Table 2). At 60 DAT, the highest number of total tillers hill $^{-1}$ (18.21) was observed in 15 January transplanting and the lowest (13.15) number of total tillers hill ${ }^{-1}$ was observed in 15 February transplanting. The number of total tillers hill ${ }^{-1}$ differed significantly at all the date of sampling due to nutrient management. The results showed that the number of total tillers hill $^{-1}$ increased with an increasing rate at different days after transplanting up to 60 DAT and thereafter declined. In case of nutrient management, at 60 DAT the highest number of total tillers hill $^{-1}(16.90)$ was recorded when fertilized with $25 \%$ less than recommended dose of inorganic fertilizers + poultry manure @ $2.5 \mathrm{t} \mathrm{ha}^{-1}$ and the lowest number of total tillers hill ${ }^{-1}$ (12.47) was recorded when fertilized with poultry manure @ 5 $\mathrm{t} \mathrm{ha}^{-1}$ (Table 2). The result was in agreement with that of Islam et al. (2014); Marzia (2015) and Jahan et al. (2017) who reported that combined application of manure with $75 \%$ recommended dose of inorganic fertilizer produced maximum number of tillers hill $^{-1}$. The highest number of total tillers hill ${ }^{-1}$ occurred due to the absorption of more nutrient, moisture and also for availability of more sunlight and the lowest number of total tillers hill ${ }^{-1}$ occurred due to lack of proper nutrient uptake. The above findings are in agreement with that of Masked et al. (1997). The interaction effect of date of transplanting and nutrient management exhibited significant influence on tiller production at all sampling dates (Table 3 ). The number of tillers hill ${ }^{-1}$ increased with an increasing rate at different days after transplanting up to 60 DAT. The result revealed that at 60 DAT the highest number of tillers (20.25) was obtained when fertilized with $25 \%$ less than recommended dose of inorganic fertilizers + poultry manure @ $2.5 \mathrm{t} \mathrm{ha}^{-1}$ and transplanted on 15 January which was at par with transplanted on 15 January and fertilized with recommended dose of inorganic fertilizers (N, P, K, S and Zn @ $115,25,60,18,3.5 \mathrm{~kg} \mathrm{ha}^{-1}$, respectively) while the lowest value (9.58) was obtained when fertilized with poultry manure @ $5 \mathrm{t}$ $\mathrm{ha}^{-1}$ and transplanted on 15 December (Table 3). After 60 DAT the number of tillers hill ${ }^{-1}$ decreased. Similar trend of tiller production was reported by Kirttania et al. (2013).

\section{Total dry matter (TDM) production}

Total dry matter production hill $^{-1}$ varied significantly at all sampling dates (Table 4). Total dry matter production hill ${ }^{-1}$ increased progressively with the advancement of time from 15 DAT to 75 DAT. The highest total dry matter accumulation (22.10 g) was obtained at 75 DAT when transplanted on 15 December and the lowest dry matter accumulation (13.86 g) was observed when transplanted on 30 January. Total dry matter production hill $^{-1}$ was significantly influenced by nutrient management at all sampling dates. Results showed that the total dry matter accumulation was increased with increase of time and initially increase of dry matter was slow. At 75 DAT, the highest total dry matter $(22.02 \mathrm{~g})$ was recorded when the crop was fertilized with $25 \%$ less than recommended dose of inorganic fertilizers + poultry manure @ $2.5 \mathrm{t} \mathrm{ha}^{-1}$ and the lowest one $(12.27 \mathrm{~g})$ was found when fertilized with only poultry manure @ $5 \mathrm{t} \mathrm{ha}^{-1}$ (Table 4). Similar trend of total dry matter hill ${ }^{-1}$ was reported elsewhere (Kirttania et al., 2013; Paul et al., 2014; Marzia, 2015 and Sarkar et al., 2016). The authors mentioned that integration of manure with $75 \%$ recommended dose of inorganic fertilizer increased total dry matter production of rice. Interaction effects of date of transplanting and nutrient management exhibited significant influence on total dry matter production at all sampling dates (Table 5). At 75 DAT, the maximum dry matter production (31.18 $\mathrm{g} \mathrm{hill}^{-1}$ ) was recorded when transplanted on 15 December and fertilized with $25 \%$ less than recommended dose of inorganic fertilizers + poultry manure @ $2.5 \mathrm{t} \mathrm{ha}^{-1}$. The lowest value of total dry matter production (9.63 $\mathrm{g} \mathrm{hill}^{-1}$ ) was observed when transplanted on 15 February and fertilized with poultry manure @ $5 \mathrm{t} \mathrm{ha}^{-1}$ which was at par with transplanted on 15 December and fertilized with poultry manure@ 5 tha $^{-1}$ (Table 5).

Leaf Area Index (LAI)

Leaf area index (LAI) was significantly affected by date of 
transplanting at 65 DAT. Figure 1 showed that the LAI (3.40) was found when the crop was transplanted on 15 February and the lowest LAI (1.74) was recorded when the crop was transplanted on 30 January. The effect of nutrient management exhibits significant influence on leaf area index at 65 DAT. In case of nutrient management, the highest leaf area index (2.78) was found when fertilized with $25 \%$ less than recommended dose of inorganic fertilizers + poultry manure @ $2.5 \mathrm{t} \mathrm{ha}^{-1}$ and the lowest leaf area index (1.98) was found when fertilized with poultry manure @ $5 \mathrm{t} \mathrm{ha}^{-1}$. The treatment having combination of organic and inorganic fertilizers showed significant improvement of LAI. Nutrient management significantly influenced the LAl was reported by Jahan et al. (2017). The result agreed with that of Paul et al. (2014) and Usman et al. (2003). In case of interaction, the results indicate that at 65 DAT there was significant interaction between date of transplanting and nutrient management. Figure 3 showed that the highest leaf area index (4.09) was obtained when transplanted on 15 February and fertilized with $50 \%$ less than recommended dose of inorganic fertilizers + poultry manure @ $2.5 \mathrm{t} \mathrm{ha}^{-1}$ which was statistically at par with transplanted on 15 February and fertilized with $25 \%$ less than recommended dose of inorganic fertilizers + poultry manure @ $2.5 \mathrm{t} \mathrm{ha}^{-1}$. The lowest leaf area index (1.32) was obtained when transplanted on 15 December and fertilized with poultry manure $5 \mathrm{t} \mathrm{ha}^{-1}$ which was statistically at par with transplanted on 15 December and fertilized with recommended dose of inorganic fertilizers.

Table 1. Effect of date of transplanting on plant height of aromatic Boro rice (cv. BRRI dhan50) at different days after transplanting.

\begin{tabular}{|c|c|c|c|c|c|}
\hline \multirow{3}{*}{ Factors and treatments } & \multicolumn{5}{|c|}{ Plant height $(\mathrm{cm})$} \\
\hline & \multicolumn{5}{|c|}{ Days after transplanting (DAT) } \\
\hline & 15 & 30 & 45 & 60 & 75 \\
\hline \multicolumn{6}{|l|}{ Date of transplanting } \\
\hline $\mathrm{D}_{1}$ & $26.89 d$ & $33.05 \mathrm{c}$ & $46.26 c$ & $60.21 c$ & $71.41 \mathrm{a}$ \\
\hline $\mathrm{D}_{2}$ & $29.48 c$ & $36.26 \mathrm{~b}$ & $51.88 \mathrm{~b}$ & $64.21 \mathrm{ab}$ & $70.15 a$ \\
\hline $\mathrm{D}_{3}$ & $30.96 b$ & $38.39 \mathrm{~b}$ & 53.01ab & $65.75 \mathrm{ab}$ & $70.73 a$ \\
\hline $\mathrm{D}_{4}$ & $33.04 a$ & 41.78a & $54.96 a$ & $67.35 a$ & $70.21 \mathrm{a}$ \\
\hline $\mathrm{D}_{5}$ & $32.90 a$ & 42.70a & $55.59 a$ & $62.74 \mathrm{bc}$ & $66.29 b$ \\
\hline $\mathrm{CV}(\%)$ & 5.55 & 6.78 & 6.00 & 6.84 & 3.10 \\
\hline \multicolumn{6}{|l|}{ Nutrient management } \\
\hline $\mathrm{F}_{1}$ & $31.24 b$ & $39.04 b$ & $53.18 b$ & $64.35 b$ & $70.48 b$ \\
\hline $\mathrm{F}_{2}$ & $27.51 c$ & $33.91 c$ & $49.28 c$ & $60.34 c$ & $66.63 c$ \\
\hline $\mathrm{F}_{3}$ & $33.07 a$ & $42.34 a$ & $55.82 a$ & $67.72 a$ & $72.79 a$ \\
\hline $\mathrm{F}_{4}$ & $30.79 b$ & $38.45 b$ & $51.07 b c$ & $63.80 \mathrm{~b}$ & $69.13 b$ \\
\hline CV (\%) & 5.55 & 6.78 & 6.00 & 6.84 & 3.10 \\
\hline
\end{tabular}

Figures in a column under each factor of treatment having the same letter or without letter do not differ significantly whereas figures with dissimilar letter differ significantly as per DMRT; $D_{1}=15$ December, $D_{2}=30$ December, $D_{3}=15$ January, $D_{4}=30$ January and $D_{5}=15$ February, $F_{1}=$ Recommended dose of inorganic fertilizers(N, P, K, S and Zn at the rate of $115,25,60,18,3.5 \mathrm{~kg} \mathrm{ha}^{-1}$ respectively), $F_{2}=$ Poultry manure $5 \mathrm{tha}{ }^{-1}, F_{3}$ $=25 \%$ less than recommended dose of inorganic fertilizers $+2.5 \mathrm{t} \mathrm{ha} \mathrm{a}^{-1}$ poultry manure, $\mathrm{F}_{4}=50 \%$ less than recommended dose of inorganic fertilizers $+2.5 \mathrm{t} \mathrm{ha}^{-1}$ poultry manure.

Table 2. Effect of date of transplanting on number of tillers hill ${ }^{-1}$ of aromatic Boro rice (cv. BRRI dhan50) at different days after transplanting.

\begin{tabular}{|c|c|c|c|c|c|}
\hline \multirow{3}{*}{ Factors and treatments } & \multicolumn{5}{|c|}{ Number of tillers hill $^{-1}$} \\
\hline & \multicolumn{5}{|c|}{ Days after transplanting (DAT) } \\
\hline & 15 & 30 & 45 & 60 & 75 \\
\hline \multicolumn{6}{|l|}{ Date of transplanting } \\
\hline $\mathrm{D}_{1}$ & $4.35 b$ & $7.11 \mathrm{c}$ & $7.94 c$ & $14.56 b$ & $13.35 b$ \\
\hline $\mathrm{D}_{2}$ & $4.46 \mathrm{~b}$ & $6.42 d$ & $7.25 d$ & $14.19 \mathrm{bc}$ & $13.62 b$ \\
\hline $\mathrm{D}_{3}$ & $3.04 d$ & $6.10 \mathrm{e}$ & $9.78 b$ & $18.21 a$ & $14.19 a$ \\
\hline $\mathrm{D}_{4}$ & $3.85 c$ & $7.88 b$ & $11.04 a$ & $15.00 \mathrm{~b}$ & $13.58 b$ \\
\hline$D_{5}$ & $6.04 a$ & $9.13 a$ & 11.00a & $13.15 c$ & $12.06 \mathrm{c}$ \\
\hline CV (\%) & 12.45 & 4.57 & 6.19 & 8.99 & 4.87 \\
\hline \multicolumn{6}{|l|}{ Nutrient management } \\
\hline $\mathrm{F}_{1}$ & 4.63ab & $7.13 c$ & $10.23 b$ & $15.78 b$ & $14.02 b$ \\
\hline $\mathrm{F}_{2}$ & $3.21 \mathrm{c}$ & $5.79 d$ & $6.98 d$ & $12.47 \mathrm{c}$ & $11.13 d$ \\
\hline $\mathrm{F}_{3}$ & $5.01 \mathrm{a}$ & $8.83 a$ & $11.07 a$ & $16.90 \mathrm{a}$ & $15.13 a$ \\
\hline $\mathrm{F}_{4}$ & $4.55 b$ & $7.55 b$ & $9.34 c$ & $14.93 b$ & $13.16 c$ \\
\hline CV (\%) & 12.45 & 4.57 & 6.19 & 8.99 & 4.87 \\
\hline
\end{tabular}

Figures in a column under each factor of treatment having the same letter or without letter do not differ significantly whereas figures with dissimilar letter differ significantly as per DMRT; $D_{1}=15$ December, $D_{2}=30$ December, $D_{3}=15$ January, $D_{4}=30$ January and $D_{5}=15$ February, $F_{1}=$

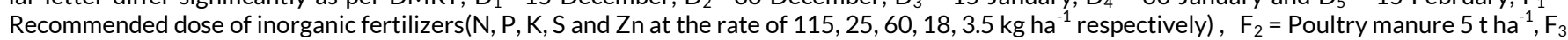
$=25 \%$ less than recommended dose of inorganic fertilizers $+2.5 \mathrm{t} \mathrm{ha}^{-1}$ poultry manure, $\mathrm{F}_{4}=50 \%$ less than recommended dose of inorganic fertilizers $+2.5 \mathrm{t} \mathrm{ha}^{-1}$ poultry manure. 
Table 3. Interaction between date of transplanting and nutrient management on number of tillers hill ${ }^{-1}$ of aromatic Boro rice (cv. BRRI dhan50) at different days after transplanting.

\begin{tabular}{|c|c|c|c|c|c|}
\hline \multirow{3}{*}{$\begin{array}{l}\text { Interaction (Date of transplanting } \times \\
\text { Nutrient management }\end{array}$} & \multicolumn{5}{|c|}{ Number of tillers hill ${ }^{-1}$} \\
\hline & \multicolumn{5}{|c|}{ Days after transplanting (DAT) } \\
\hline & 15 & 30 & 45 & 60 & 75 \\
\hline $\mathrm{D}_{1} \times \mathrm{F}_{1}$ & $4.80 \mathrm{~cd}$ & 6.00ghi & 10.25de & 15.42cdef & 14.00def \\
\hline $\mathrm{D}_{1} \times \mathrm{F}_{2}$ & 3.86defg & 6.17fgh & $5.00 \mathrm{k}$ & $9.585 \mathrm{~h}$ & $9.670 \mathrm{j}$ \\
\hline $\mathrm{D}_{1} \times \mathrm{F}_{3}$ & $4.80 \mathrm{~cd}$ & $8.75 c$ & 9.582ef & $18.58 a b$ & $16.25 a b$ \\
\hline $\mathrm{D}_{1} \times \mathrm{F}_{4}$ & 3.93defg & $7.50 \mathrm{~d}$ & $6.92 \mathrm{i}$ & 14.67cdefg & $13.48 \mathrm{ef}$ \\
\hline $\mathrm{D}_{2} \times \mathrm{F}_{1}$ & $4.66 \mathrm{cde}$ & 5.66hi & $8.00 \mathrm{~h}$ & $14.58 \mathrm{cdefg}$ & $14.42 \mathrm{cde}$ \\
\hline $\mathrm{D}_{2} \times \mathrm{F}_{2}$ & 3.16ghi & $5.50 \mathrm{i}$ & $5.75 \mathrm{jk}$ & $12.92 \mathrm{fg}$ & $11.58 \mathrm{i}$ \\
\hline $\mathrm{D}_{2} \times \mathrm{F}_{3}$ & $5.17 c$ & $7.33 d$ & 8.83fgh & $15.58 \mathrm{cde}$ & $15.42 b c$ \\
\hline $\mathrm{D}_{2} \times \mathrm{F}_{4}$ & $4.83 \mathrm{~cd}$ & 7.17de & $6.42 \mathrm{ij}$ & $13.67 \mathrm{defg}$ & 13.08fgh \\
\hline $\mathrm{D}_{3} \times \mathrm{F}_{1}$ & 3.42fghi & 5.83hi & 9.42efg & $19.83 a$ & $15.50 b c$ \\
\hline $\mathrm{D}_{3} \times \mathrm{F}_{2}$ & $2.50 \mathrm{i}$ & 4.33j & $6.98 i$ & 13.92defg & $10.25 j$ \\
\hline $\mathrm{D}_{3} \times \mathrm{F}_{3}$ & 3.08ghi & $7.66 \mathrm{~d}$ & $11.75 b c$ & $20.25 a$ & $17.08 a$ \\
\hline $\mathrm{D}_{3} \times \mathrm{F}_{4}$ & 3.16ghi & $6.58 \mathrm{efg}$ & $11.00 \mathrm{~cd}$ & 18.83ab & 13.92def \\
\hline $\mathrm{D}_{4} \times \mathrm{F}_{1}$ & 3.83defg & $8.42 c$ & 12.00abc & $15.67 \mathrm{~cd}$ & $14.08 \mathrm{def}$ \\
\hline $\mathrm{D}_{4} \times \mathrm{F}_{2}$ & $2.75 \mathrm{hi}$ & $6.25 \mathrm{fgh}$ & $8.750 f g h$ & 13.33defg & 12.25ghi \\
\hline $\mathrm{D}_{4} \times \mathrm{F}_{3}$ & $4.58 \mathrm{cde}$ & $9.67 b$ & 12.33ab & $16.50 \mathrm{bc}$ & $14.75 \mathrm{~cd}$ \\
\hline $\mathrm{D}_{4} \times \mathrm{F}_{4}$ & $4.25 \mathrm{cdef}$ & 7.17de & $11.08 c d$ & $14.50 \mathrm{cdefg}$ & $13.25 \mathrm{efg}$ \\
\hline $\mathrm{D}_{5} \times \mathrm{F}_{1}$ & $6.41 \mathrm{~b}$ & $9.75 b$ & $11.50 b c$ & 13.42defg & 12.08ghi \\
\hline $\mathrm{D}_{5} \times \mathrm{F}_{2}$ & 3.75efgh & 6.67ef & 8.420gh & $12.58 \mathrm{~g}$ & 11.92hi \\
\hline $\mathrm{D}_{5} \times \mathrm{F}_{3}$ & $7.41 a$ & $10.7 a$ & $12.83 a$ & $13.58 \mathrm{defg}$ & 12.17ghi \\
\hline $\mathrm{D}_{5} \times \mathrm{F}_{4}$ & $6.58 a b$ & $9.33 b$ & $11.25 \mathrm{~cd}$ & 13.00efg & 12.08ghi \\
\hline CV (\%) & 12.45 & 4.57 & 6.19 & 8.99 & 4.87 \\
\hline
\end{tabular}

In a column, Figures with the same letters or without letter do not differ significantly whereas figures with dissimilar letter differ significantly as per DMRT; $D_{1}=15$ December, $D_{2}=30$ December, $D_{3}=15$ January, $D_{4}=30$ January and $D_{5}=15$ February, $F_{1}=$

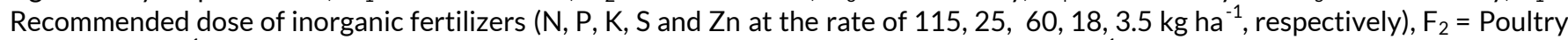
manure $5 \mathrm{t} \mathrm{ha}^{-1}, \mathrm{~F}_{3}=25 \%$ less than recommended dose of inorganic fertilizers $+2.5 \mathrm{t} \mathrm{ha} \mathrm{h}^{-1}$ poultry manure, $\mathrm{F}_{4}=50 \%$ less than recommended dose of inorganic fertilizers $+2.5 \mathrm{t} \mathrm{ha}^{-1}$ poultry manure.

Table 4. Effect of date of transplanting on total dry matter production hill ${ }^{-1}$ ) of aromatic Boro rice (cv. BRRI dhan50) at different days after transplanting.

\begin{tabular}{|c|c|c|c|c|c|}
\hline \multirow{3}{*}{ Factors and treatments } & \multicolumn{5}{|c|}{ Total dry matter production (g hill ${ }^{-1}$ ) } \\
\hline & \multicolumn{5}{|c|}{ Days after transplanting (DAT) } \\
\hline & 15 & 30 & 45 & 60 & 75 \\
\hline \multicolumn{6}{|l|}{ Date of transplanting } \\
\hline $\mathrm{D}_{1}$ & $0.6300 d$ & $1.886 d$ & $2.299 d$ & $11.22 \mathrm{c}$ & $22.10 a$ \\
\hline $\mathrm{D}_{2}$ & $0.8425 c$ & $1.653 d$ & $4.767 c$ & $17.12 a$ & $19.19 \mathrm{~b}$ \\
\hline $\mathrm{D}_{3}$ & $0.2833 e$ & $2.628 \mathrm{c}$ & $4.655 c$ & $13.02 b$ & $16.61 c$ \\
\hline $\mathrm{D}_{4}$ & $2.181 b$ & $5.724 a$ & $6.129 \mathrm{~b}$ & $16.72 a$ & $16.77 c$ \\
\hline $\mathrm{D}_{5}$ & $2.538 a$ & $5.308 b$ & $7.596 a$ & $12.56 \mathrm{~b}$ & $13.86 \mathrm{~d}$ \\
\hline CV (\%) & 5.37 & 8.94 & 6.67 & 5.58 & 7.05 \\
\hline \multicolumn{6}{|l|}{ Nutrient management } \\
\hline $\mathrm{F}_{1}$ & $1.471 b$ & $3.533 b$ & $5.217 \mathrm{~b}$ & $15.15 b$ & $18.62 b$ \\
\hline $\mathrm{F}_{2}$ & $1.017 d$ & $2.794 d$ & $3.450 c$ & $9.525 c$ & $12.27 c$ \\
\hline $\mathrm{F}_{3}$ & $1.582 \mathrm{a}$ & $4.252 a$ & $5.905 a$ & $17.07 a$ & $22.02 a$ \\
\hline $\mathrm{F}_{4}$ & $1.110 c$ & $3.179 c$ & $5.785 a$ & $14.76 b$ & $17.91 \mathrm{~b}$ \\
\hline CV (\%) & 5.37 & 8.94 & 6.67 & 5.58 & 7.05 \\
\hline
\end{tabular}

Figures in a column under each factor of treatment having the same letter or without letter do not differ significantly whereas figures with dissimilar letter differ significantly as per DMRT; $D_{1}=15$ December, $D_{2}=30$ December, $D_{3}=15$ January, $D_{4}=30$ January and $D_{5}=15$ February, $F_{1}=$ Recommended dose of inorganic fertilizers (N, P, K, S and Zn at the rate of $115,25,60,18,3.5 \mathrm{~kg}^{-1}$ respectively), $\mathrm{F}_{2}=\mathrm{Poultry}$ manure $5 \mathrm{t}$ ha ${ }^{-1}, \mathrm{~F}_{3}$ $=25 \%$ less than recommended dose of inorganic fertilizers $+2.5 \mathrm{tha}^{-1}$ poultry manure, $\mathrm{F}_{4}=50 \%$ less than recommended dose of inorganic fertilizers $+2.5 \mathrm{t} \mathrm{ha}^{-1}$ poultry manure. 
Table 5. Effect of interaction between date of transplanting and nutrient management on total dry matter production hill ${ }^{-1}$ of aromatic Boro rice (cv. BRRI dhan50) at different days after transplanting.

\begin{tabular}{|c|c|c|c|c|c|}
\hline \multirow{3}{*}{$\begin{array}{l}\text { Interaction (Date of transplanting } \times \\
\text { Nutrient management) }\end{array}$} & \multicolumn{5}{|c|}{ Total dry matter production (g hill ${ }^{-1}$ ) } \\
\hline & \multicolumn{5}{|c|}{ Days after transplanting (DAT) } \\
\hline & 15 & 30 & 45 & 60 & 75 \\
\hline $\mathrm{D}_{1} \times \mathrm{F}_{1}$ & $0.64 \mathrm{~g}$ & 1.85hi & $2.80 \mathrm{~h}$ & $12.02 \mathrm{~g}$ & $23.92 b$ \\
\hline $\mathrm{D}_{1} \times \mathrm{F}_{2}$ & $0.43 \mathrm{~h}$ & $1.13 \mathrm{j}$ & $1.67 i$ & $7.260 \mathrm{~h}$ & $10.43 g$ \\
\hline $\mathrm{D}_{1} \times \mathrm{F}_{3}$ & $0.93 f$ & $2.53 \mathrm{fg}$ & $2.91 \mathrm{~h}$ & $11.62 \mathrm{~g}$ & $31.18 a$ \\
\hline $\mathrm{D}_{1} \times \mathrm{F}_{4}$ & $0.52 \mathrm{~h}$ & $2.02 \mathrm{gh}$ & $1.81 \mathrm{i}$ & $13.96 f$ & $22.88 b$ \\
\hline $\mathrm{D}_{2} \times \mathrm{F}_{1}$ & $0.94 f$ & $1.34 \mathrm{ij}$ & $4.94 \mathrm{fg}$ & $18.59 c$ & $19.61 \mathrm{c}$ \\
\hline $\mathrm{D}_{2} \times \mathrm{F}_{2}$ & $0.72 \mathrm{~g}$ & $1.25 \mathrm{j}$ & $2.48 \mathrm{~h}$ & $11.27 \mathrm{~g}$ & $13.94 f$ \\
\hline $\mathrm{D}_{2} \times \mathrm{F}_{3}$ & $0.85 f$ & $2.64 f$ & $6.43 \mathrm{~cd}$ & $19.99 \mathrm{~b}$ & $23.94 b$ \\
\hline $\mathrm{D}_{2} \times \mathrm{F}_{4}$ & $0.86 f$ & $1.38 \mathrm{ij}$ & $5.21 f$ & $18.62 \mathrm{c}$ & $19.26 c$ \\
\hline $\mathrm{D}_{3} \times \mathrm{F}_{1}$ & $0.30 \mathrm{i}$ & $3.25 \mathrm{e}$ & $5.01 \mathrm{fg}$ & 15.74de & $18.37 \mathrm{~cd}$ \\
\hline $\mathrm{D}_{3} \times \mathrm{F}_{2}$ & $0.23 \mathrm{i}$ & $1.46 \mathrm{ij}$ & $3.08 \mathrm{~h}$ & $8.150 h$ & $14.14 f$ \\
\hline $\mathrm{D}_{3} \times \mathrm{F}_{3}$ & $0.30 \mathrm{i}$ & $3.38 \mathrm{e}$ & $4.54 \mathrm{~g}$ & 16.31de & $18.59 \mathrm{~cd}$ \\
\hline $\mathrm{D}_{3} \times \mathrm{F}_{4}$ & $0.29 \mathrm{i}$ & $2.42 \mathrm{fg}$ & $5.99 \mathrm{de}$ & $11.88 \mathrm{~g}$ & $15.35 \mathrm{ef}$ \\
\hline $\mathrm{D}_{4} \times \mathrm{F}_{1}$ & $2.86 a$ & $5.32 \mathrm{c}$ & $6.66 c$ & $17.05 d$ & $17.55 \mathrm{cde}$ \\
\hline $\mathrm{D}_{4} \times \mathrm{F}_{2}$ & $1.70 d$ & $7.172 a$ & $4.56 \mathrm{~g}$ & $12.36 \mathrm{~g}$ & $13.21 \mathrm{f}$ \\
\hline $\mathrm{D}_{4} \times \mathrm{F}_{3}$ & $2.91 a$ & $5.810 \mathrm{bc}$ & $6.85 c$ & $21.84 a$ & $19.64 c$ \\
\hline $\mathrm{D}_{4} \times \mathrm{F}_{4}$ & $1.25 \mathrm{e}$ & $4.593 d$ & $6.44 \mathrm{~cd}$ & $15.63 e$ & 16.70de \\
\hline $\mathrm{D}_{5} \times \mathrm{F}_{1}$ & $2.61 b$ & $5.903 b$ & $6.67 c$ & $12.34 \mathrm{~g}$ & $13.65 f$ \\
\hline $\mathrm{D}_{5} \times \mathrm{F}_{2}$ & $2.00 c$ & $2.953 \mathrm{ef}$ & 5.45ef & $8.580 \mathrm{~h}$ & $9.633 \mathrm{~g}$ \\
\hline $\mathrm{D}_{5} \times \mathrm{F}_{3}$ & $2.92 a$ & $6.897 a$ & $8.79 b$ & $15.61 \mathrm{de}$ & $16.76 \mathrm{de}$ \\
\hline $\mathrm{D}_{5} \times \mathrm{F}_{4}$ & $2.62 \mathrm{~b}$ & $5.480 \mathrm{bc}$ & $9.46 a$ & $13.72 f$ & $15.38 \mathrm{ef}$ \\
\hline CV (\%) & 5.37 & 8.94 & 6.67 & 5.58 & 7.05 \\
\hline
\end{tabular}

In a column, Figures with the same letters or without letter do not differ significantly whereas figures with dissimilar letter differ significantly as per DMRT; $D_{1}=15$ December, $D_{2}=30$ December, $D_{3}=15$ January, $D_{4}=30$ January and $D_{5}=15$ February; $F_{1}=$ Recommended dose of inorganic fertilizers ( $N, P, K, S$ and $Z n$ at the rate of $115,25,60,18,3.5 \mathrm{~kg} \mathrm{ha}^{-1}$, respectively), $F_{2}=$ Poultry manure $5 \mathrm{t} \mathrm{ha}^{-1}, F_{3}=25 \%$ less than recommended dose of inorganic fertilizers $+2.5 \mathrm{t} \mathrm{ha}^{-1}$ poultry manure, $\mathrm{F}_{4}=50 \%$ less than recommended dose of inorganic fertilizers $+2.5 \mathrm{t}^{-1} \mathrm{a}^{-1}$ poultry manure.

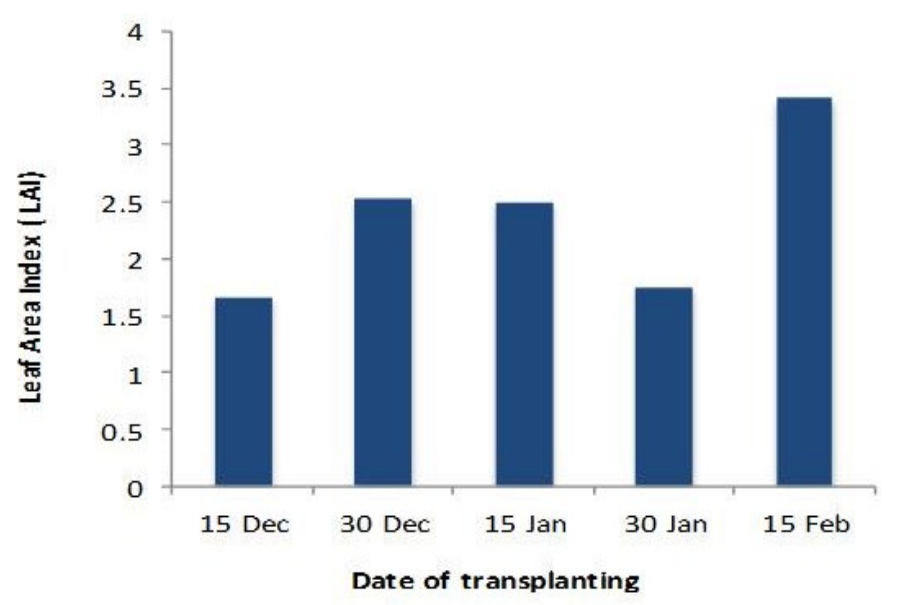

Figure 1. Effect of date of transplanting on leaf area index (LAI) of aromatic Boro rice (cv. BRRI dhan50) at 65 DAT.

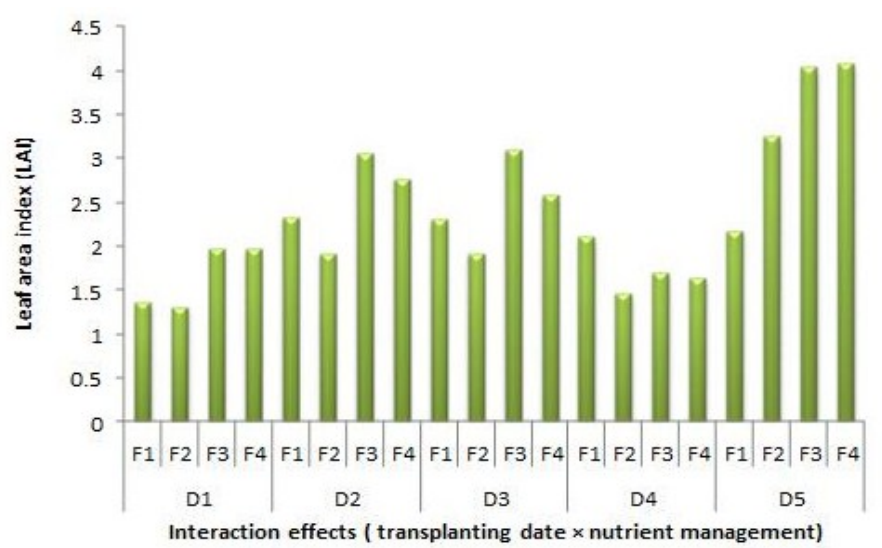

Figure 3. Effect of interaction between date of transplanting and nutrient management on leaf area index (LAl) of aromatic Boro rice (cv. BRRI dhan50) at 65 DAT.

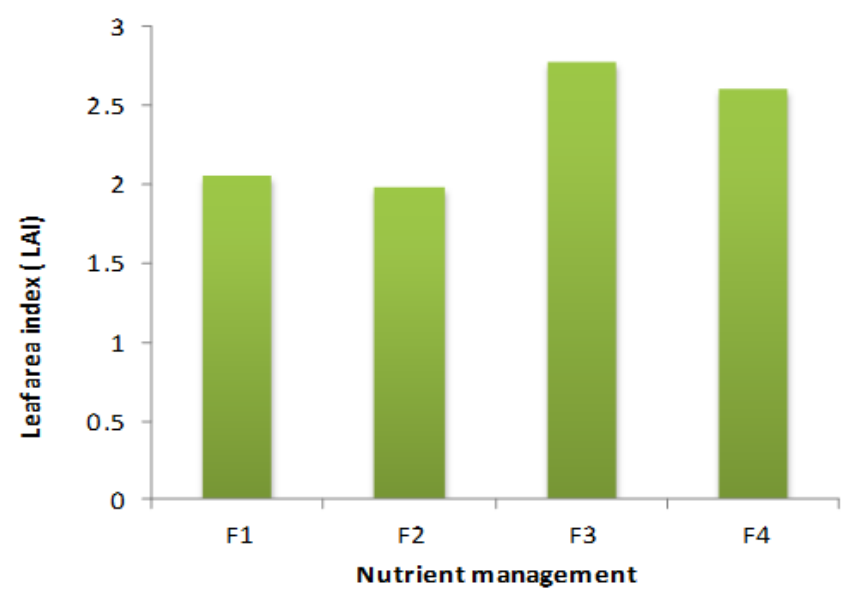

Figure 2. Effect of nutrient management on leaf area index (LAI) of aromatic Boro rice (cv. BRRI dhan50) at 65 DAT.

\section{Conclusion}

The tallest plant was recorded in early transplanting (15 December) while the shortest one was recorded in delay transplanting (15 February). The highest number of tillers hill ${ }^{-1}$ and leaf area index were obtained in $25 \%$ less than recommended dose of inorganic fertilizers + poultry manure @ $2.5 \mathrm{t} \mathrm{ha}^{-1}$. The highest dry matter production hill $^{-1}$ was obtained when the crop was transplanted on 15 December and fertilized with $25 \%$ less than recommended dose of inorganic fertilizers + poultry manure @ $2.5 \mathrm{t} \mathrm{ha}^{-1}$. Therefore, aromatic Boro rice (cv. BRRI dhan50) can be transplanted on 15 December fertilized with $25 \%$ less than recommended dose of inorganic fertilizers + poultry manure @ $2.5 \mathrm{t} \mathrm{ha}^{-1}$ for appreciable growth performance. 


\section{ACKNOWLEDGEMENT}

The financial assistant (39.009.002.01.00.057.2015-2016/BS06/935) of Ministry of Science and Technology, Government of the People's Republic of Bangladesh to carry out this research work is thankfully acknowledged.

Open Access: This is open access article distributed under the terms of the Creative Commons Attribution License, which permits unrestricted use, distribution, and reproduction in any medium, provided the original author(s) and the source are credited.

\section{REFERENCES}

Aljumaili, S.J., Rafii, M.Y., Latif, M.A., Sakimin,S.Z., Arolu, I.W. and Miah, G. (2018). Genetic diversity of aromatic rice germplasm revealed by SSR markers. BioMed Research International, ID: 7658032 pp. 11, https://doi.org/10.1155/ 2018/7658032

Ashrafuzzaman, M., Islam, M. R., Ismail, M.R., Shahidullah, S.M. and Hanafi, M.M. (2009). Evaluation of six aromatic rice varieties for yield and yield contributing characters. International Journal of Agriculture \& Biology, 11: 616-620; http:// agris.fao.org/agris-search/ search.do? record ID= PK2010000129

BBS, Bangladesh Bureau of Statistics (2016). The yearbook of agricultural statistics of Bangladesh. Statistics Division, Ministry of Planning, Government of People's Republic of Bangladesh. Dhaka, pp. 49, http://bbs.portal. gov.bd/sites/default /files/files/ bbs.portal.gov.bd/page/ b2db8758_8497_412c_a9ec_6bb299f8b3ab/ Statistical YearBookFinal2016.pdf

BRRI, Bangladesh Rice Research Institute (2003). Annual Internal Review held on 19-23 October, Genetic Resources and Seed division, Bangladesh Rice Research Institute, Gazipur, pp. 6-8.

Gomez, K.A. and Gomez, A.A. (1984). Statistical procedure for agricultural research. International Rice Research Institute, Philippines, John Wiley and Sons. New York, Chichester, Brisbane, Toronto, Singapore, pp. 680.

Islam, S.M.M., Paul, S.K., Sarkar, M.A.R. and Miah, M.A.M. (2014). Growth of transplant Aman rice as influenced by weeding regime and integrated nutrient management. Bangladesh Journal of Progressive Science and Technology, 12(1): 49-54.

Jahan, S., Sarkar, M.A.R. and Paul, S.K. (2017). Variations of growth parameters in transplanted Aman rice (cv. BRRI dhan39) in response to plant spacing and fertilizer management. Archives of Agriculture and Environmental Science, 2(1): 1-5,https://www.aesacademy.org/journal/volume2/issue1/ AAES-02-01-01.pdf

Kirttania, B., Sarkar, M.A.R. and Paul, S.K. (2013). Performance of transplant Aman rice as influenced by tiller seedlings and nitrogen management. Journal of the Bangladesh Agricultural University, 11(2): 249-256, http://dx.doi.org/10.3329/ jbau.v11i2.19903

Marzia, R. (2015). Effect of row arrangement and integrated nutrient management on the growth and yield of aromatic fine rice cv. BRRI dhan34. MS Thesis. Department of Agronomy Bangladesh Agricultural University Mymensingh, pp. 41-50.

Masked, N.S., Borkar, S.I. and Rajgir, H.J. (1997). Effect of N levels on growth, yield and grain quality of rice. Journal of Soils and Crops, 7(1): 83-86.

Paul, S.K, Islam, S.M.M., Sarkar, M.A.R., Alam, A. and Zaman, F. (2014). Physiological parameters of transplant Aman rice (cv. BRRI dhan49) as influenced by weeding regime and integrated nutrient management. Journal of Agroforestry and Environment, 8(2): 121-125.

Sarkar, S.K., Sarkar, M.A.R., Islam, N. and Paul, S.K. (2016). Morpho-physiological attributes of three HYV aromatic fine rice varieties as affected by integrated nutrient management. Journal of Agroforestry and Environment, 10(1): 57-61.

Singh, Y. and U.S. Singh. (2008). Genetic diversity analysis in aromatic rice germplasm using agro- morphological traits. Journal of Plant Genetic Resource, 21(1): 32-37.

UNDP and FAO. (1988). Land Resources Appraisal of Bangladesh for Agricultural Development. In Report 2, 212-221. Agroecological Regions of Bangladesh. United Nation Development Programme and Food and Agriculture Organization.

Usman, M., Ullah, E., Wareiach, E.A., Faruq, M. and Liaqat, A. (2003). Effect of organic and inorganic manures on growth and yield of rice variety "Basmati-2000". Journal of Bioscience and Agriculture Research, 5(4): 481-483. 